\title{
EFFECTS OF ICE AND SNOW COVER ON THE CHEMISTRY OF NEARSHORE LAKE WATER DURING SPRING MELT
}

\author{
by
}

J.M. Gunn*

(Ontario Ministry of Natural Resources, Sudbury, Ontario P3A 4S2, Canada)

\author{
and W. Keller
}

(Ontario Ministry of Environment, Sudbury, Ontario P3E 5P9, Canada)

\section{ABSTRACT}

Snow and ice played important roles in determining the occurrence and timing of $\mathrm{pH}$ depressions in the shallow $(\sim 1 \mathrm{~m})$ nearshore waters of a small lake of the Canadian Shield. The influences of the terrestrial snowpack and lake-surface snow on the chemical composition of under-ice water were distinctly different. On land, acidic meltwater from snow was enriched with lithological elements in the soil/litter layer during lateral movement to the lake shoreline. The resulting run-off water was of relatively high ionic strength ( $\overline{\mathrm{X}}$ conductivity $\left.55 \mu \mathrm{S} \mathrm{cm}^{-1}\right)$, low $\mathrm{pH}(\overline{\mathrm{X}} 4.1)$ and contained high concentrations of Al ( $\left.\overline{\mathrm{X}} 1786 \mu \mathrm{g} \mathrm{1^{-1 }}\right)$, an element potentially toxic to aquatic biota. Snow cover on the ice surface controlled thermal conditions in the underlying water, dictating the depth to which run-off water penetrated. Uniformly cold conditions $\left(<2{ }^{\circ} \mathrm{C}\right)$ allowed penetration of run-off water to the substrate while under-ice warming to $4{ }^{\circ} \mathrm{C}$ resulted in surface layering of less dense run-off water. Flooding of the ice with lake water and melting of the ice and snow-surface cover served to counteract the effects of the run-off water through dilution.

\section{INTRODUCTION}

High concentrations of acid precursors and other airborne pollutants have been found in precipitation from around the world (reviewed in Haines 1981). In areas with cold winters, pollutants collect on and within the snowpack, and are transported to aquatic ecosystems during periods of melt (Hagen and Langeland 1973, Hultberg 1977, Jeffries and others 1979). Much of the observed damage to fish and other sensitive aquatic organisms (Harvey and others 1981) has been attributed to acidification resulting from pulses of acidic run-off water during snow-melt. Although considerable concern has been expressed recently over the biological effects of spring snow-melt, little attention has been focused to date on the roles of within-lake processes, related to snow and ice cover, as controls on nearshore water chemistry.

To address the question of within-lake processes, a study was conducted of the chemical and physical changes occurring at shallow nearshore, sites on Whitepine Lake (lat $47^{\circ} 17^{\prime} \mathrm{N}$, long $80^{\circ} 50^{\prime} \mathrm{W}$ ) during snow-melt and ice break-up. The sites are representative of the spawning habitat of lake trout (Salvelinus namaycush) in this low pH (5.7), low alkalinity (40 $\mu$ eq $1^{-1}$ ) lake. The investigation was conducted as part of a study into the cause of recruitment failure of lake trout. The hatching and emergence of lake trout during snow-melt and ice break-up results in the exposure of sensitive life stages to potentially detrimental chemical conditions (Gunn and Keller 1984).

The objective of the present study was to determine if the surface cover of snow and ice was responsible for any of the observed changes in the chemistry of nearshore waters. Our hypothesis was that the surface cover exerted a direct effect on underlying water quality during melt and also modified the impact of terrestrial run-off water. In this paper we characterize the components of snow and ice cover in our study area, and, by using examples from the spring of 1984 , illustrate some effects of the winter cover on the chemistry of nearshore waters.

\section{STUDY SITE}

Whitepine Lake is a headwater lake $67 \mathrm{ha}^{2}$ in area located $90 \mathrm{~km}$ north of Sudbury, Ontario. Its watershed $\left(328 \mathrm{ha}^{2}\right)$ consists of a boreal forest cover, thin sandy soils and granitic bedrock. Further details on the characteristics of the lake and the surrounding area are available in Gunn and Keller (1984). In late winter the lake ice and terrestrial snow cover are both about 60 $\mathrm{cm}$ deep. There are occasional winter rains and thaws, but the major period of snow-melt and ice break-up generally occurs from late April to early May. During our study period, the dates of complete ice clearance varied from 28 April to 10 May (Fig.1).

Extensive nearshore areas experience $\mathrm{pH}$ depressions during the spring melt period (Fig.1), and these depressions occur while the lake is still covered with ice. After ice-out, spatial variability in $\mathrm{pH}$ is greatly reduced and the nearshore areas become chemically similar to midlake waters.

For this study, three main sites were used: a midlake site and two shoreline sites located $70 \mathrm{~m}$ apart

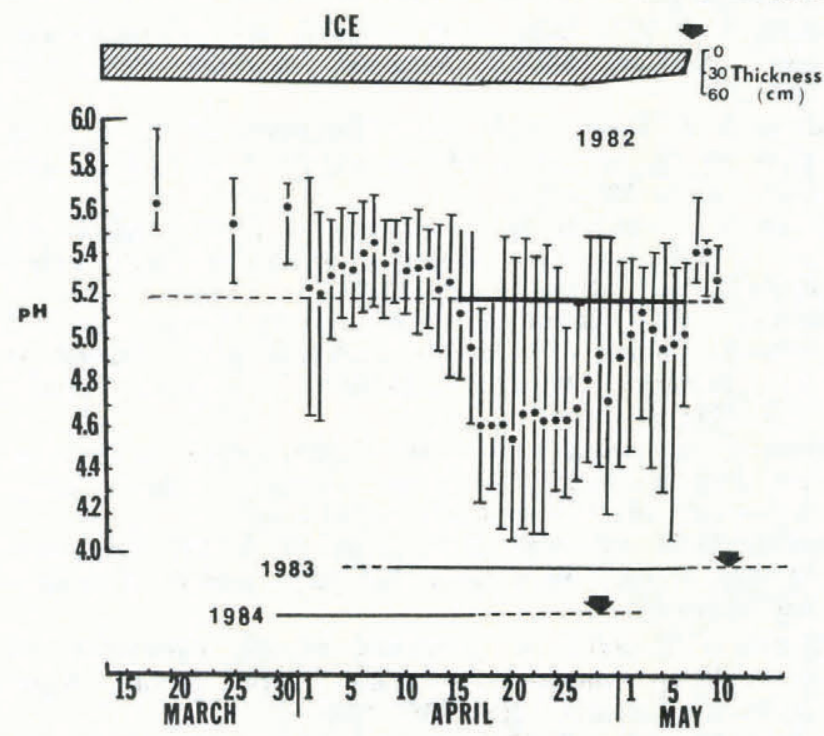

Fig. 1. Mean and range of $\mathrm{pH}$ at the $1 \mathrm{~m}$ level for ten nearshore sites on Whitepine Lake, 1982. Date of ice clearance ( ) and sampled periods of mean $\mathrm{pH}<5.2$ $(-)$ and $>5.2(---)$ for other study years are indicated.

* Present address: Department of Zoology, University of Guelph, Guelph, Ontario N1G 2W1, Canada. 


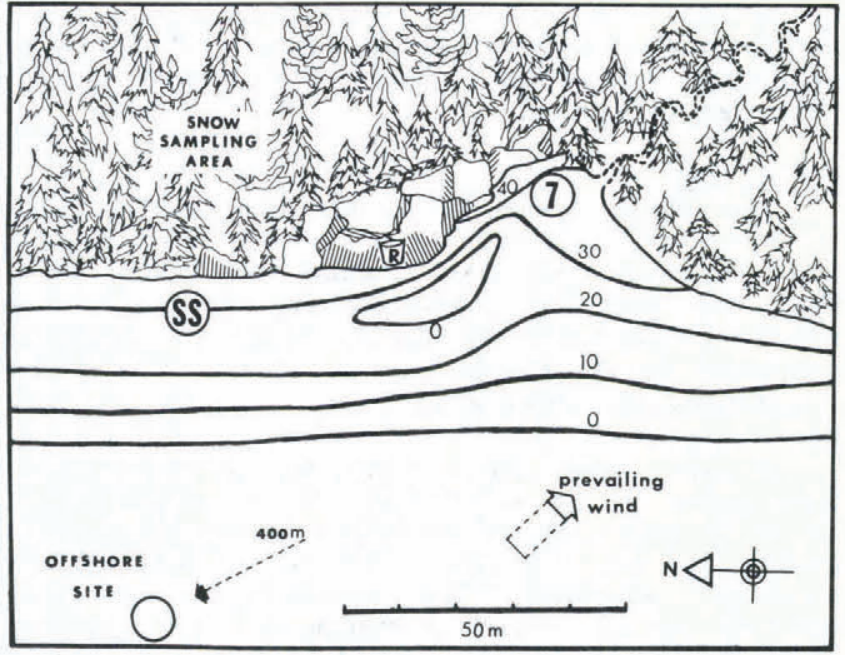

Fig. 2. Locations of chemistry-monitoring sites, run-off collector (R), and snow-sampling area. Isopleths indicate snow depth $(\mathrm{cm})$ on the ice during early April 1984.

(Fig.2). The shoreline sites exhibit important physical differences. Site 7 is located in a small bay where heavy snow accumulation results in positive hydrostatic pressure beneath the ice leading to frequent flooding with lake water. Site 7 is also influenced by its proximity to a small drainage channel that periodically floods the area with terrestrial run-off water. Site SS is more windswept, has less snow, usually exhibits a negative hydrostatic level, and receives run-off directly from the adjacent hillside only.

\section{PROCEDURES}

Four to six snow-core samples were collected in the forested area above site SS (Fig.2) on several occasions during mid to later winter and at weekly intervals during the spring melt period. A "drip" collector (Nalgene pail) positioned under an overhanging rock face, located between the shoreline sites ( $R$ in Fig.2), was used to determine relative daily run-off rates and to collect samples for chemical analysis.

In late winter, holes were sawn through the ice at sites SS and 7 , and white plastic collars were frozen into place at each site (Fig.3). The collars reduced disturbance of the snow and ice cover at the site, prevented surface inflows, and allowed collection of water samples and the measurement of water depth and ice thickness. Lids were installed to exclude

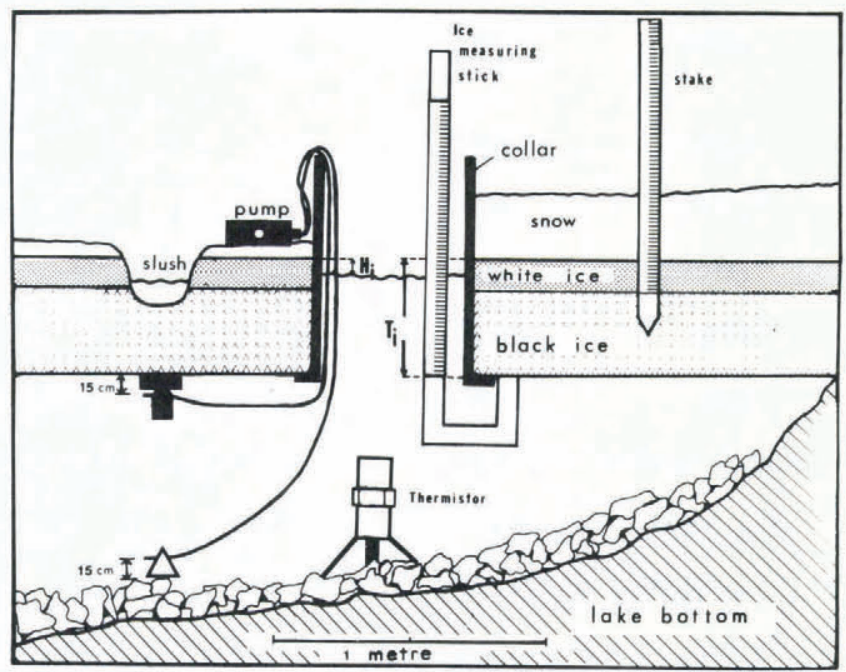

Fig. 3. Cross-sectional diagram of nearshore monitoring station representative of conditions at site SS during early April 1984. Ti: total ice, Hi: hydrostatic level. precipitation. Snow and white- and black-ice thicknesses were measured daily using modifications of the procedures described by Adams and Prowse (1981) (illustrated in Fig.3).

Water samples were drawn through tygon tubing with a peristaltic pump from $15 \mathrm{~cm}$ above the substrate surface and from $15 \mathrm{~cm}$ below the ice.

Daily readings of temperature and dissolved $\mathrm{O}_{2}$ were carried out in situ (YSI model 54 meter) and a continuous reading thermistor was positioned on the bottom throughout the melt period (Fig.3). Relative illumination through the ice and snow cover was measured with a luxmeter. The sensor was suspended at a constant point under the ice, and the opening of the collar was covered with black plastic to exclude direct light during measurement.

During 1984, ice blocks were removed at sites SS and 7 at the time of collar installation. Additional blocks were removed periodically at the mid-lake site and, on a single occasion, at sites along the shoreline to the south of site 7 (Fig.2). The blocks were sectioned into the visibly distinguishable layers, and water content, $\mathrm{pH}$, and conductivity were determined for each layer. Volume-weighted samples of the white- and black-ice zones were generated by pooling appropriate aliquots from individual layers, and samples were analyzed for trace-metal and major ion content. Visibly coloured (yellow-brown) layers were analyzed separately.

Holes were drilled to the level of the black-ice zone in order to collect slush water (Fig.3). Slush samples were collected at irregular intervals throughout the winter but daily during the spring melt period.

Conductivity and $\mathrm{pH}$ were measured within $24 \mathrm{~h}$ of sample collection at either the Whitepine Lake field station or the Ministry of the Environment (MOE) laboratory in Sudbury. Other analyses were performed on samples submitted to the MOE laboratory in Toronto. Further details of sample collection and analysis are

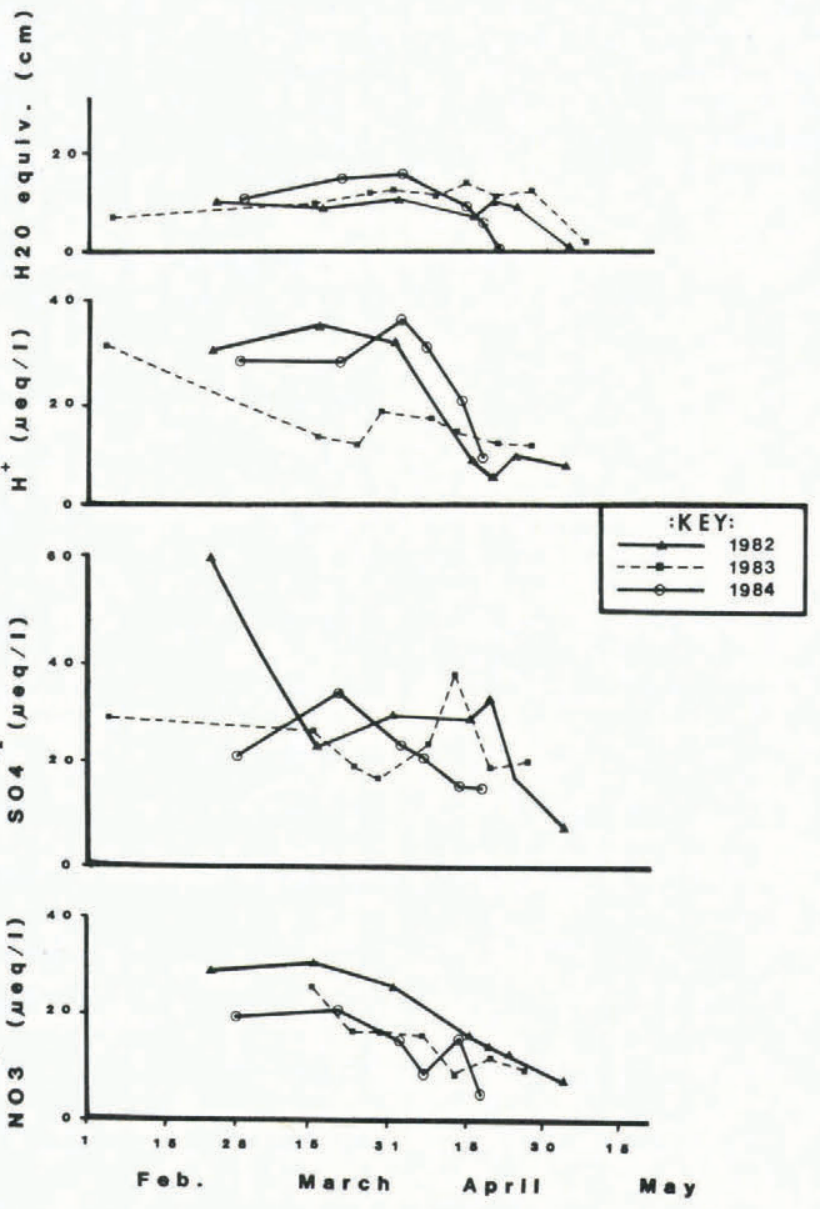

Fig. 4. Temporal changes in water equivalent, $\mathrm{H}^{+}, \mathrm{SO}_{4}^{2-}$ and $\mathrm{NO}_{3}^{-}$concentrations in the terrestrial snowpack, 1982-84. 
available in Ministry of Environment, Ontario (1981) and Gunn and Keller (1984).

\section{RESULTS AND DISCUSSION}

\section{Snowpack and run-off}

Although the ionic composition of the terrestrial snowpack was similar between study years, temporal variations within and between years were noted (Fig.4). Consistent with the observations of Johannessen and Henricksen (1977) and Jeffries and Snyder (1981), depletion of $\mathrm{H}^{+}, \mathrm{SO}_{4}^{2-}$ and $\mathrm{NO}_{3}^{-}$occurred in the snowpack throughout winter and spring. However, evaluation of ion depletion patterns was complicated by alternate periods of freezing and thawing and precipitation events which occurred during each study period. Concentrations of other major ions did not show any obvious depletion, but other mechanisms may override the importance of downward ion loss from the snowpack. In boreal forest situations such as our study area, snowpack concentrations of ions such as $\mathrm{K}^{+}$and $\mathrm{Ca}^{2+}$ may be greatly influenced by inputs of organic debris (Jones 1985, Jones and Sochanska 1985).

The chemical composition of run-off during the snow-melt period was substantially different from that of the snowpack (Table I). In comparison to the snowpack, run-off showed average enrichment of $\sim 115$ 45-, 13-, 12-, 9-, 7-, 6-, and 3-fold for $\mathrm{SiO}_{3} \mathrm{Al}$, colour, $\mathrm{Fe}, \mathrm{SO}^{2-}, \mathrm{Mg}^{2+}, \mathrm{Ca}^{2+}$, and $\mathrm{H}^{+}$, respectively, while $\mathrm{NO}^{-}$ essentially disappeared. Although preferential ion release during melting (Colbeck 1981) may have contributed to the high concentrations of some solutes in run-off water, elevations in lithologically derived constituents present at low levels in the snowpack such as $\mathrm{SiO}_{3}, \mathrm{Fe}$ and $\mathrm{Al}$ indicate strong interaction of meltwater with terrestrial soils and litter. Mackay (1983) has shown that substantial water movement into the ground occurs even under frozen conditions.

Peaks in run-off conductivity were observed near the beginning and end of snow-melt. The generally higher ionic strength near the commencement of melt may reflect the pressing out of old soil water stored in the catchment over winter (Johannessen and others 1980) while peaks near the end of snow-melt may relate to increased contact with and penetration into soils. An alternative explanation is that dilution with meltwater during the major run-off periods resulted in lower conductivities; however, run-off volume did not show significant correlations $(p>0.1)$ with any of the parameters in Table I.

Ice and slush

The spatial distribution of the snow and ice cover on Whitepine Lake was similar to that described for other temperate zone lakes (Adams and Prowse 1981). The cover type and thickness were less variable in mid-lake where snow was thin or absent, and black ice dominated. In the nearshore areas, snow and white ice accumulated and extreme variability in cover type and thickness existed.

In later winter, the lake ice $(60 \mathrm{~cm})$ represented a large source $\left(\sim 3.6 \times 10^{5} \mathrm{~m}^{3}\right)$ of dilute (conductivity $<10$ $\mu \mathrm{S} \mathrm{cm}^{-1}$ ) water, almost equivalent to maximum water

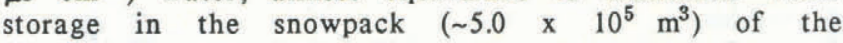
terrestrial watershed. The concentrations of most elements in the black-ice component were generally lower than in white ice (Table I). Solutes are removed from ice by freeze-out processes. Downward migration of solutes from black ice to the underlying water occurs (Gröterud 1978, Adams and Lasenby 1982), a process most efficient under slow, prolonged freezing conditions (Adams 1981). Solutes exsolved from white ice, formed during periods of flooding followed by rapid freezing, collect in slush layers at the white ice/black ice interface (Hagen and Langeland 1973, Jones and Ouellet 1983 ) or enter the lake through cracks.

The nearshore cover showed some chemical characteristics different from those of the offshore cover (Fig.5). Yellow-brown bands of low pH (4.5 to 4.9), relatively high conductivity (19 to $44 \mu \mathrm{S} \mathrm{cm}^{-1}$ ) water with comparatively high concentrations of lithological elements such as Al (120 to $400 \mu \mathrm{g}^{-1}$ ) and $\mathrm{Fe}$ (45 to $105 \mu \mathrm{g}^{-1}$ ) were observed in the nearshore ice. These coloured bands were the result of midwinter thaws causing terrestrial run-off that mixed with the snow at the nearshore areas and later froze to form part of the white-ice layer.

Not all nearshore areas had ice with obvious terrestrial input. For example, at the time of collar installation the ice at site SS resembled offshore ice. It was mainly black ice $(18 \mathrm{~cm})$, and the thin layer of

TABLE I. CHEMICAL COMPOSITION OF SNOW, ICE, LAKE AND RUN-OFF WATER, WHITEPINE LAKE 1984 (Data expressed as mean value \pm standard deviation (number of samples)

\begin{tabular}{|c|c|c|c|c|c|}
\hline & Snowpack* & Run - of $f$ & White ice & Black ice & Lake water** \\
\hline Date & $1 / 3-18 / 4$ & $29 / 3-28 / 4$ & $20 / 3-20 / 4$ & $20 / 3-20 / 4$ & $30 / 3$ \\
\hline $\begin{array}{l}\text { Conductivity } \\
\left(\mu \mathrm{S} \mathrm{cm}^{-1} \text { at } 25^{\circ} \mathrm{C}\right)\end{array}$ & $15 \pm 2(6)$ & $55 \pm 0(27)$ & $7 \pm 3(6)$ & $4 \pm 2(6)$ & 36 \\
\hline $\mathrm{H}^{+}\left(\mu \mathrm{eq} 1^{-1}\right)$ & $25 \pm 9(6)$ & $84 \pm 12(28)$ & $6 \pm 3(6)$ & $3 \pm 1(6)$ & 2 \\
\hline 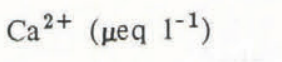 & $11 \pm 1(6)$ & $70 \pm 31(7)$ & $4 \pm 3(6)$ & $2 \pm 1(6)$ & 148 \\
\hline $\mathrm{Mg}^{2+}\left(\mu\right.$ eq $\left.\mathrm{l}^{-1}\right)$ & $5 \pm 1(6)$ & $37 \pm 10(7)$ & $2 \pm 1(6)$ & $1 \pm 0(6)$ & 72 \\
\hline $\mathrm{SO}_{4}^{2-}\left(\right.$ eеq $\left.1^{-1}\right)$ & $22 \pm 6(6)$ & $207 \pm 86(7)$ & $12 \pm 5(6)$ & $6 \pm 6(6)$ & 248 \\
\hline $\mathrm{NO}_{3}^{-}\left(\mu\right.$ eq $\left.1^{-1}\right)$ & $14 \pm 6(6)$ & $1 \pm 0(7)$ & $3 \pm 1(6)$ & $1 \pm 0(6)$ & 2 \\
\hline $\mathrm{SiO}_{3}\left(\mathrm{mg} \mathrm{l}^{-1}\right)$ & $<0.02(6)$ & $2.3 \pm 1.4(7)$ & $0.03 \pm .03(6)^{* * *}$ & $<0.02(5)$ & 0.84 \\
\hline Al $\left(\mu \mathrm{g} \mathrm{l}^{-1}\right)$ & $40 \pm 14(6)$ & $1786 \pm 376(7)$ & $32 \pm 35(6)$ & $21 \pm 2(5)$ & 69 \\
\hline $\mathrm{Fe}\left(\mu \mathrm{g} \mathrm{1^{-1 }}\right)$ & $33 \pm 9(6)^{* * *}$ & $394 \pm 54(7)$ & $22 \pm 13(6)^{* * *}$ & $11 \pm 5(5)^{* * *}$ & 30 \\
\hline Colour $(\mathrm{Hu})$ & $10 \pm 6(6)$ & $133 \pm 7(7)$ & $1 \pm 0(6)$ & $1 \pm 0(6)$ & 4 \\
\hline
\end{tabular}

* Each sample consisted of five replicate cores.

** $5 \mathrm{~m}$ tube composite sample collected under ice at mid-lake.

*** May be overestimates; mean included some values reported as "less than". 


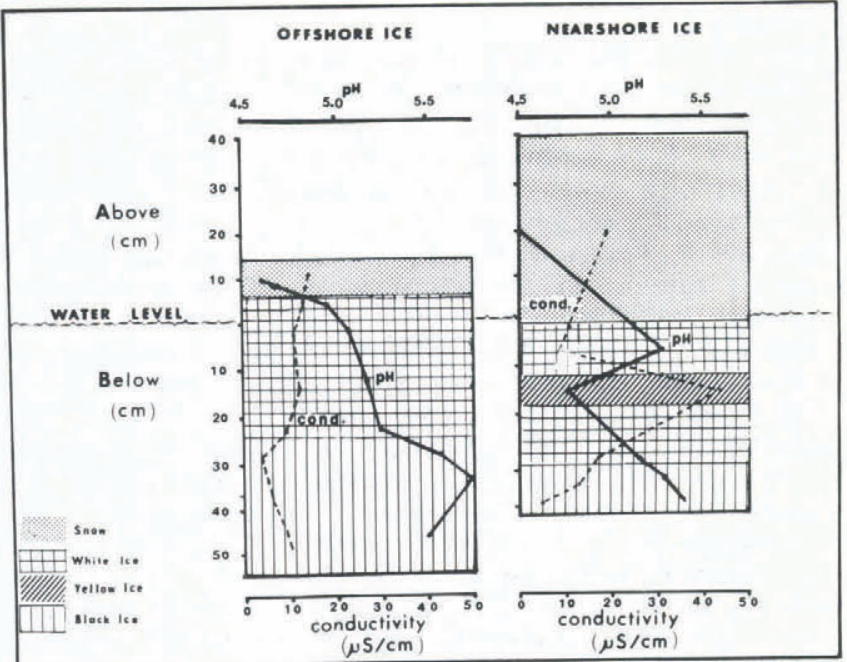

Fig. 5. Profiles of $\mathrm{pH}$ and conductivity in the of fshore and nearshore surface cover on 22 March 1984.

white ice $(4.5 \mathrm{~cm})$ was colourless. In contrast, at site 7 a thin layer of black ice $(6 \mathrm{~cm})$ was overlain by three white-ice layers (total $26 \mathrm{~cm}$ ) separated by two coloured, still unfrozen slush layers (total $13 \mathrm{~cm}$ ). The thicker snowpack and the proximity to the drainage channel at site 7 (Fig.2) appeared to be responsible for the high proportion of white ice and the presence of run-off water at this site.

The chemical composition of the slush water at sites SS and 7 demonstrated the range of conditions observed (Fig.6). At site SS, a site with a negative hydrostatic level, the late winter slush was a concentrated (conductivity: $250 \mu \mathrm{S} \mathrm{cm} \mathrm{cm}^{-1}, \mathrm{Ca}^{2+}: 760 \mu \mathrm{eq} \mathrm{I}^{-1}, \mathrm{SO}_{4}^{2-}: 1550$

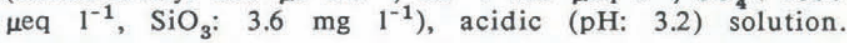
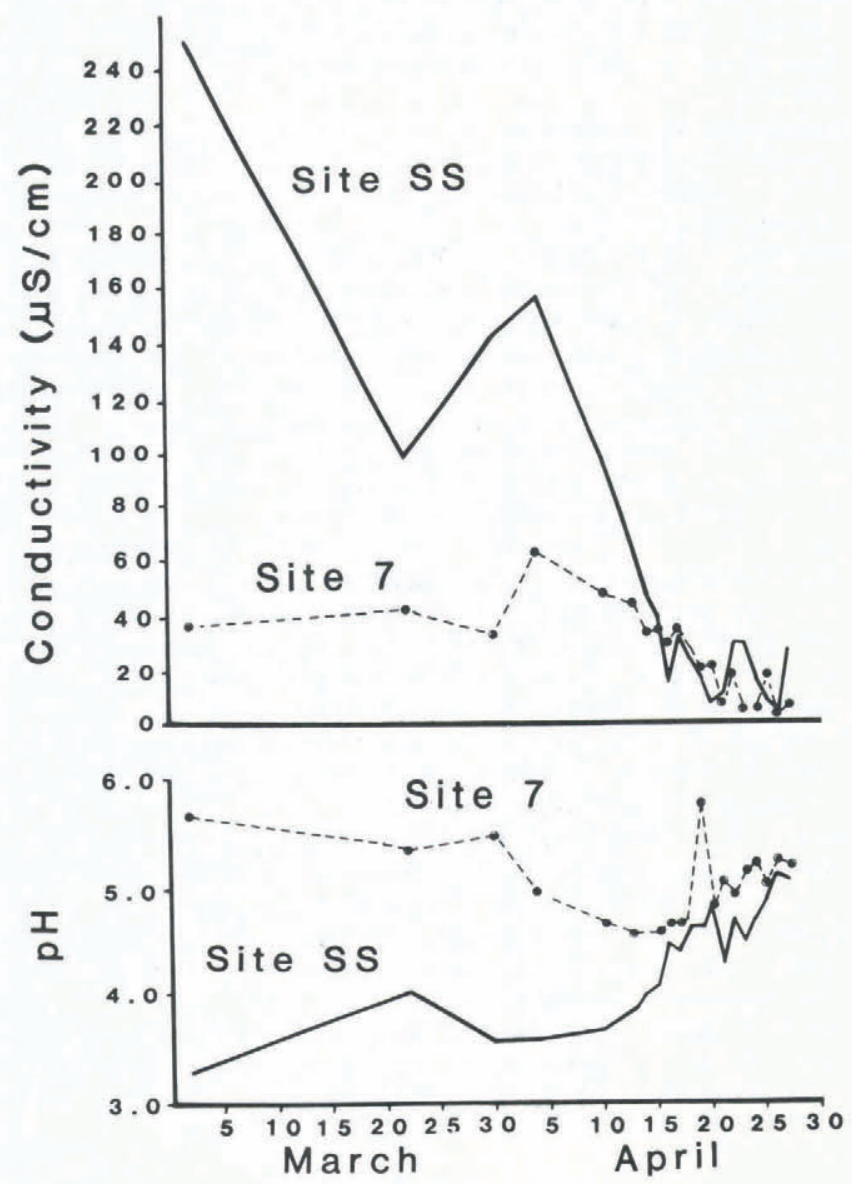

Fig. 6. Temporal changes in the conductivity and $\mathrm{pH}$ of slush water at sites 7 and SS, 1984.
Dilution by melting snow and ice water reduced the solute concentrations in the slush throughout the melt period. At site 7, flooding of the ice related to the heavy snow load resulted in midwinter slush samples similar in chemistry to ambient lake water. During the melt period, solute content of the site 7 slush increased through the addition of relatively concentrated terrestrial run-off, but then declined through dilution with meltwater and lake water (Fig.6).

\section{Under-ice water}

During the melt period, nearshore waters exhibited large temporal changes in most chemical and physical parameters (Fig.7). The changing conditions represented the mixing of lake water with water from three sources: land (run-off), lake surface (snow and ice meltwater) and atmosphere (precipitation).

Direct input of precipitation appeared to be relatively insignificant during our 1984 melt period. Total precipitation during 28 March-28 April 1984 amounted to $30.2 \mathrm{~mm}$ of which only $16.8 \mathrm{~mm}$ fell as rain.

The chemical characteristics of lake-surface components and terrestrial run-off were sufficiently different (Table I) for their individual effects to be differentiated readily.

At site SS, the under-ice surface water (top sampler) was affected by two separate run-off events during each of which it exhibited increases in conductivity, colour, $\mathrm{SiO}_{3}, \mathrm{Al}$ and $\mathrm{Fe}$, and a decrease in $\mathrm{pH}$, reflecting input of terrestrial run-off water (Fig.7). The direct effect of the surface cover was evident only after the final run-off event. The melting of the surface cover caused reductions in solute concentration of the lake water through dilution with the meltwater.

The findings at site 7 demonstrated a second feature of the surface cover that affected under-ice water quality. The weight of snow and slush at site 7 depressed the ice pack causing flooding of the area by ambient lake water and the accumulation of meltwater from the surface cover. This layer of mixed water above the ice pack served to lessen the effects of the terrestrial input. For example, during the first run-off event at site 7 (3-5 April, Fig.7) little surface water was present and the effects of the run-off (i.e. $\mathrm{pH}$ decrease, conductivity increase) were even more pronounced than the effects at site SS. However, during the much larger

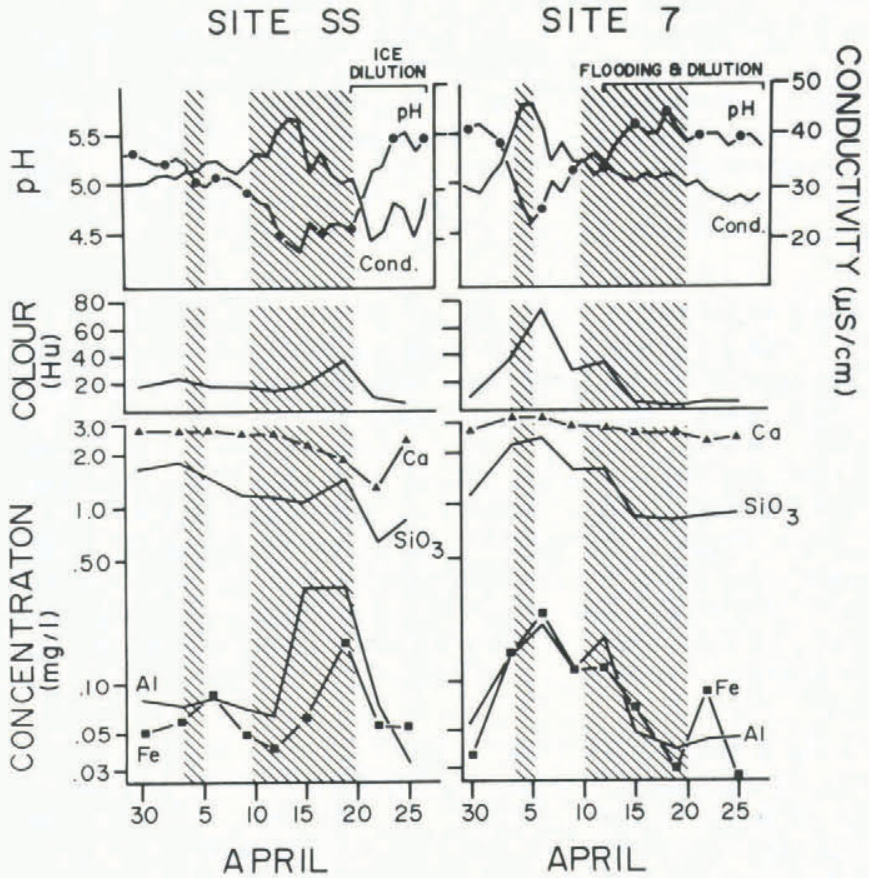

Fig. 7. Chemical composition of the under-ice water (15 $\mathrm{cm}$ below ice pack) at sites SS and 7, spring 1984. The shaded areas indicate the main periods during which terrestrial run-off occurred (see second panel, Fig.8) 


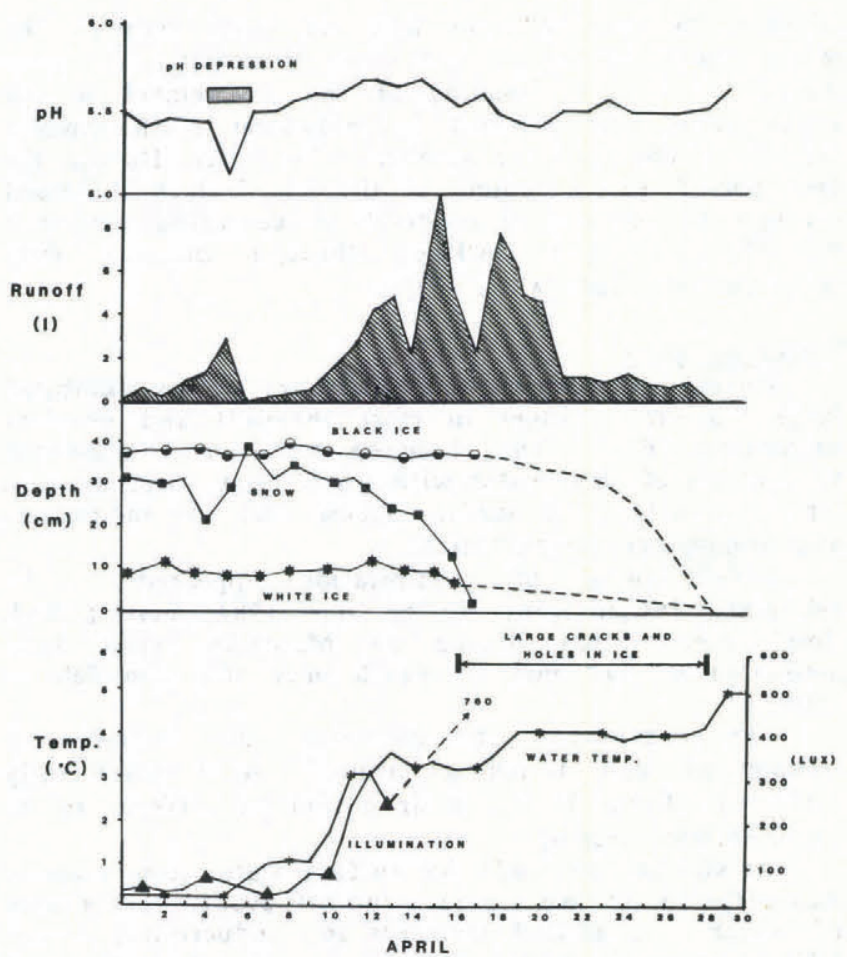

Fig. 8. Timing of $\mathrm{pH}$ depression to the substrate level at site SS relative to daily run-off volume, surface-cover composition, under-ice illumination and water temperature.

second run-off event, (10-20 April, Fig.7) the area was flooded with lake water and meltwater, and the run-off appeared to have had no effect on under-ice water chemistry. Indeed, solute concentrations in the under-ice water decreased during the second run-off event, indicating that dilution by water from the eroding cover was occurring as well.

Thermal/density conditions in the under-ice water appeared to determine the depth to which run-off water penetrated. Snow is the principal component of the surface cover that controls the radiant flux responsible for under-ice warming (Pivovarov 1973, Maguire 1975).

Penetration of run-off water to the $1 \mathrm{~m}$ substrate level (bottom sampler) occurred only under cold $\left(<2{ }^{\circ} \mathrm{C}\right)$ water temperatures (Fig.8). With the loss of snow cover, under-ice illumination (and presumably infrared input) increased while the temperature rose to $4^{\circ} \mathrm{C}$. After this rise, the cold, less dense run-off water layered at the surface and did not reach the fish habitat.

\section{CONCLUSIONS}

The nearshore spawning habitat of Salvelinus namaycush is threatened by episodic inputs of run - off water containing potentially toxic levels of $\mathrm{H}^{+}$and Al. The surface cover of ice and snow can alter these effects through dilution, above and below the ice pack and by controlling under-ice thermal stratification.

It appears that, with regard to water quality, the worst conditions for incubating eggs and fry occur when run-off reaches the nearshore area before ice melt and the complete loss of snow cover. Further quantitative analysis of the data is continuing.

\section{ACKNOWLEDGEMENTS}

R Furchner, P Gale, V Liimatainen, D Polkinghorne, K Ricker, D Smith and E Snucins provided technical assistance, L Barrie, P Dillon, J Lye, W Scheider and D Whelpdale reviewed the manuscript. This project was supported in part through funds provided by the Acid Precipitation in Ontario Study (APIOS), a cooperative programme of the Ontario Ministries of Environment and Natural Resources.

\section{REFERENCES}

Adams W P 1981 Snow and ice on lakes. In Gray D M, Male D H (eds) Handbook of snow; principles, processes, management and use. Toronto, Pergamon Press: 437-474

Adams W P, Lasenby D C 1982 Lake ice growth and conductivity. Proceedings of the Western Snow Conference, 39th annual meeting: 184-185

Adams W P, Prowse T D 1981 Evolution and magnitude of spatial patterns in the winter cover of temperate lakes. Fennia 159(2): 343-359

Colbeck S C 1981 A simulation of the enrichment of atmospheric pollutants in snow cover runoff. Water Resources Research 17(5): 1383-1388

Gröterud O 1978 Cryochemistry of lakes with special reference to formation, distribution and effect of phosphorus and hydronium. Verhandlungen der Internationalen Vereinigung für Theoretische und Angewandte Limnologie 20: 758-764

Gunn J M, Keller W 1984 Spawning site water chemistry and lake trout (Salvelinus namaycush) sac fry survival during spring snowmelt. Canadian Journal of Fisheries and Aquatic Sciences 41(2): 319-329

Hagen A, Langeland A 1973 Polluted snow in southern Norway and the effect of the meltwater on freshwater and aquatic organisms. Environmental Pollution 5: 45-57

Haines T A 1981 Acidic precipitation and its consequences for aquatic ecosystems: a review. Transactions of the American Fisheries Society 110: 669-707

Harvey $\mathrm{H} \mathrm{H}$, Pierce $\mathrm{R}$ C, Dillon $\mathrm{P} J$, Kramer $\mathrm{J}$ R, Whelpdale D M 1981 Acidification in the Canada aquatic environment. Ottawa, National Research Council of Canada. Environmental Secretariat (Publication 18475)

Hultberg H 1977 Thermally stratified acid water in late winter - a key factor inducing self-accelerating processes which increase acidification. Water, Air and Soil Pollution 7: 279-294

Jeffries D S, Snyder W R 1981 Variations in the chemical composition of the snowpack and associated meltwaters in central Ontario. Proceedings of the Eastern Snow Conference, 38th annual meeting: 11-22

Jeffries D S, Cox C M, Dillon P J 1979 Depression of $\mathrm{pH}$ in lakes and streams in central Ontario during snowmelt. Journal of the Fisheries Research Board of Canada 36(6): 640-646

Johannessen M, Henriksen A 1977 Chemistry of snowmelt water: changes in concentration during melting. SNSF (Sur Nedbors Virkning pá Skog og Fisk) Technical Report FR11/77

Johannessen M, Skartveit A, Wright R F 1980 Streamwater chemistry before, during and after snowmelt. In Drabløs D, Tollan A (eds) Ecological impact of acid precipitation. Proceedings of an international conference, Sandefjord. Norway, March 11-14, 1980. Oslo - Às, SNSF (Sur Nedbørs Virkning på Skog og Fisk) Project: 224-225

Jones H G 1985 The chemistry of snow and meltwaters within the mesostructure of a northern boreal forest snow cover. Annals of Glaciology 7: 161-166

Jones H G, Ouellet M 1983 Caractéristiques physico-chimiques et microbiologiques de la couverture de glace de quelques lacs. Eau du Québec 16(2): 174-181

Jones H G, Sochanska W 1985 The chemical characteristics of snow cover in a northern boreal forest during the spring run-off period. Annals of Glaciology 7: 167-174

Mackay J R 1983 Downward water movement into frozen ground, western Arctic coast, Canada. Canadian Journal of Earth Sciences 20(1): 120-134

Maguire R J 1975 Light transmission through snow and ice. Environment Canada. Inland Waters Directorate. Canadian Center for Inland Waters. Scientific Series 91: 1-4

Ministry of the Environment, Ontario 1981 Outlines of analytical methods. Toronto, Ontario Ministry of the Environment (Technical Report)

Pivovarov A A 1973 Thermal conditions in freezing lakes and rivers. New York etc, John Wiley and Sons (Israel Program for Scientific Translations) 